\title{
Assessing the forest-wood chain at local level: A Multi-Criteria Decision Analysis (MCDA) based on the circular bioeconomy principles
}

\author{
Elisa Pieratti', Alessandro Paletto's, Isabella De Meo', Claudio Fagarazzi², \\ Matteo Rillo Migliorini Giovannini²
}

Pieratti E., Paletto A., De Meo I., Fagarazzi C., Migliorini Giovannini M. R., 2019. Assessing the forest-wood chain at local level: A Multi-Criteria Decision Analysis (MCDA) based on the circular bieconomy principles. Ann. For. Res. 62(1): _-_.

Abstract. In the last years, the circular bioeconomy has been recognized as key approach to increase the competitiveness of enterprises and economic growth in the European Union (EU) member countries. Forest-based sector plays a key role in the circular bioeconomy. The aim of the present study is to analyze the forest-wood chain at local level following the circular bioeconomy approach. A set of indicators to quantify the 4R ("Reduce", "Reuse", "Recycle", "Recover") of circular economy has been defined and tested in a study area in Italy (Monte Morello forest in Tuscany region). The indicators identified and tested are: improving production process efficiency; reuse and life-span of wood products; optimization of potential wood assortments and energy recover from the wood products. By means of the indicators and a Multi-Criteria Decision Analysis (MCDA), the current forest management strategy applied in the study area has been compared with other possible forest management scenarios in order to evaluate the optimum solution. The results show that the current forest management strategy did not optimize the productive function because the wood harvested is wholly allocated for bioenergy production. The economic value and the life-span of wood products can be increased by means of the wood harvested valorization. Anyway, the results show a favorable balance concerning the carbon dioxide $\left(\mathrm{CO}_{2}\right)$ emission - considering the fossil fuel substitution effect - and the bioenergy production from deadwood.

Keywords: circular bioeconomy indicators, forest management strategies, cascading approach, bioenergy, renewable energy policy

Authors. ${ }^{1}$ Consiglio per la ricerca in agricoltura e l'analisi dell'economia agraria (CREA) $\mid{ }^{2}$ University of Florence.

§Corresponding author: Alessandro Paletto (allessandro.paletto@crea.gov.it)

Manuscript received March 8, 2019; revised June 24, 2019; accepted July 2, 2019; online first July 12, 2019. 


\section{Introduction}

In the last century - due to the increased use of natural resources, global environmental degradation, and human-induced climate change impact - the linear fossil-based economy paradigm has been discussed and questioned by the scientific community and the decision makers (Mohan et al. 2016, Hetemäki et al. 2017).

Recently, as pointed out at the Paris Climate Conference (CoP21) in December 2015, the circular bioeconomy has become the alternative paradigm to the linear economic one (Bruhn et al. 2016). From the theoretical point of view, the circular bioeconomy combines in a hierarchical way the two concepts of circular economy and bioeconomy (D'Amato et al. 2017, Murray et al. 2015). According to the Ellen MacArthur Foundation (2014) the circular economy can be defined as restorative and regenerative by design, and aimed to keep products, components and materials at their highest utility and value, distinguishing between technical and biological cycles. The core principle of circular economy is the $\mathrm{R}$ framework, developed at first as 3R framework ("Reduce", "Reuse", "Recycle") and then evolved in 4R when in 2008 the EU Waste Framework Directive introduced "Recover" as the fourth $\mathrm{R}$ (European Commission 2008).

In the 4R framework, the hierarchy among the $\mathrm{R}$ is fundamental (Van Buren et al. 2016): the first R ("Reduce") is considered to be a priority to the second $\mathrm{R}$ and so on. This hierarchical relationship is closely linked to the "cascade" principle that implies the use of raw materials according to a priority based on the added potential value (Proskurina et al. 2016). Therefore, raw wood materials should be preferably used for building, furniture and other products with long life span, while bioenergy should preferably derive from the use of wood residues or recycled products (Ciccarese et al. 2014).

When considering bioeconomy, the EU Strategy for "Innovating for Sustainable
Growth: A Bioeconomy for Europe" (2012) has defined bioeconomy as the sustainable production of renewable resources from land, fisheries and aquaculture environments and their conversion into food, feed, fiber biobased products and bioenergy as well as the related public goods. In the EU member countries, the bioeconomy sector has a market size of over 2 trillion $€$ and provides 22 million jobs across diverse sectors - agriculture, forestry, food, chemicals, and bioenergy - corresponding to around $9 \%$ of the total EU labour force (Hetemäki 2014).

In the circular bioeconomy, forest-based sector plays a key role accounting more than 20\% of EU's bioeconomy sectors (Hetemäki 2014). In the coming decades, paper and paperboard consumption in EU should decrease, while in accordance with the Renewable Energy Directive 2009/28/EC and the Energy Strategy 2020 the wood consumption for energy generation should increase (Grilli et al. 2017a).

In this context, the availability of indicators to assess the impacts of forest management practices through the circular bioeconomy's principles could help to evaluate forest-based sector at local level. These indicators should highlight the economic and environmental impacts of different forest management practices (e.g., clearcutting, selective cutting, shelterwood cutting, thinning) considering the 4R framework of circular economy and the hierarchical position of the individual $\mathrm{R}$. The most suitable method for considering the hierarchy between $4 \mathrm{R}$ is the Multiple-Criteria Decision Analysis (MCDA) approach aimed to solving complex problems that are characterized as a choice among alternatives such as forest management practices (Grilli et al. 2017b). Another suitable approach is the Life Cycle Assessment (LCA), a widely used method for assessing the potential environmental and climate change impacts throughout a product's (or service's) lifecycle. This approach has found several applications in the forestry sector as highlighted by Klein et al. (2015). The LCA provides a large set of environmen- 
tal indicators, identifying air and waterborne emissions as well as resources consumption associated with the product or service's production process (Pehnt 2006). The LCA can be applied in order to highlight the potential negative environmental effects of the linear economy compared to the circular economy as shown by Scheepens et al. (2016).

Starting from these considerations, the aim of the present study is to identify a set of indicators to assess the economic and environmental impact of forest management practices at local level following the principles of the circular bioeconomy. The indicators have been tested in an Italian case study involved in the project LIFE14 CCM/IT/905 "Recovery of degraded coniferous Forests for environmental sustainability Restoration and climate change Mitigation" (FoResMit). The indicators have been applied in a black pine (Pinus nigra J.F. Arnold) forest where two different forest management practices (selective thinning and traditional thinning) were implemented. Subsequently, the MCDA approach has been used to compare the different forest management scenarios to guide decision makers in choosing the optimal scenario.

\section{Materials and methods}

\section{Study area}

The study area is Monte Morello forest (435'ㅇ' $\mathrm{N}$; $\left.11^{\circ} 14^{\prime} 23^{\prime \prime} \mathrm{E}\right)$ in Tuscany region (Central Italy). Since XII century, due to its proximity with Florence town, Monte Morello forest was strongly used as wood source for buildings and energy. At the beginning of $\mathrm{XX}$ century, a reforestation was carried out in order to provide hydrogeological stability in mountainous areas depleted by the intensive use of natural resources (Cantiani \& Chiavetta 2015). From 1909 to 1980 , a surface of 1,035 ha has been reforested using mainly conifers (78\% of the total species) such as common cypress (Cupressus sempervirens L.), cypress of Arizona (Cupressus arizonica E. Greene), black pine (Pinus nigra J.F. Arnold), and Calabrian pine (Pinus brutia Ten.). For the remaining $22 \%$, local broadleaved species were used such as Downy oak (Quercus pubescens Willd.), Turkey oak (Quercus cerris L.) and Holm oak (Quercus ilex L.).

After the reforestation, forest management practices (e.g., thinning, sanitary cuttings) have rarely been applied in Monte Morello forest. Consequently, forest stands have been largely abandoned with important consequences on tree stability, mortality and increase of fire risk. Currently, the average growing stock is around $560 \mathrm{~m}^{3} \mathrm{ha}^{-1}$, while deadwood volume is around $75 \mathrm{~m}^{3} \mathrm{ha}^{-1}$ (80\% lying deadwood, $18 \%$ standing dead trees, $2 \%$ stumps), mainly belonging to the second and third decay class (De Meo et al. 2017).

In 2015, the LIFE FoResMit project was developed applying two different silvicultural treatments (traditional thinning and selective thinning) aimed to improve the stand characteristics and the forest multifunctionality of Monte Morello (Mazza et al. 2019). The two silvicultural treatments were applied on a pilot area of 10.08 ha (Table 1): (1) selective thinning $(4.73 \mathrm{ha})$ : in this thinning the choice of the trees to be cut is based on a positive selection (thinned $30-40 \%$ of basal area). Standing dead trees and lying deadwood of first and second decay class with diameter at breast height (DBH) more than $20 \mathrm{~cm}$ are removed during the silvicultural treatments, (2) traditional thinning (5.35 ha): in this thinning the choice of the trees to be cut is based on a negative selection (thinned from below $15-20 \%$ of basal area). Small and leaned trees and standing dead trees are removed, while the lying deadwood is not removed during the silvicultural treatments.

\section{Research framework}

The study was structured in three steps: (1) 
analyzing of forest-wood chain at local level considering raw materials and energy flow among the different phases (felling, harvesting, chipping, transport, and energy conversion); (2) defining a set of circular bioeconomy indicators for the forest-wood chain; (3) testing the set of circular bioeconomy indicators to the case study using a Multiple-Criteria Decision Analysis (MCDA).

In this study, six indicators have been defined in order to assess the efficiency of forest wood-chain considering the 4R framework (see Table 2). The basic assumptions used to develop the indicators for forest-wood chain are that high value products are preferred to low value products, and that the energy use of wood must be considered as the last option when other alternatives are not viable ("cascade" approach).

Reduce. Reduce means increasing the process efficiency by consuming fewer natural resources and materials. Reduce has been quantified as the economic valorization of the wood harvested in a forest area unit and the reduction of carbon dioxide $\left(\mathrm{CO}_{2}\right)$ emissions for a wood volume unit harvested. Both indicators can be considered an indirect measure of the forest resource consumption to produce a product unit $\left(\mathrm{m}^{3}\right.$ of wood) or of the production process efficiency. To "measure" the Reduce principle in the forest management practices, the indicators $\mathrm{I}_{1}$ and $\mathrm{I}_{2}$ have been calculated as follows (eq.1 and 2):

Table 1 Volume of growing stock and deadwood harvested in Monte Morello forest

\begin{tabular}{lcc}
\hline & Traditional thinning & Selective thinning \\
\hline Forest area (ha) & 5.35 & 4.73 \\
\hline Growing stock $\left(\mathrm{m}^{3} \mathrm{ha}^{-1}\right)$ & 134.70 & 202.00 \\
\hline $\begin{array}{l}\text { Deadwood removed for unit area (standing and } \\
\text { lying) }\left(\mathrm{m}^{3} \mathrm{ha}^{-1}\right)\end{array}$ & 9.50 & 18.20 \\
\hline Volume harvested for unit area $\left(\mathrm{m}^{3} \mathrm{ha}^{-1}\right)$ & 144.20 & 220.20 \\
\hline Total volume harvested $\left(\mathrm{m}^{3}\right)$ & 772.00 & 1042.00 \\
\hline
\end{tabular}

Table 2 Indicators based on the 4R framework of the circular bioeconomy

\begin{tabular}{|c|c|c|}
\hline $4 \mathrm{R}$ & Definition & Indicator defined for the forest sector \\
\hline Reduce & $\begin{array}{l}\text { Improving of the process } \\
\text { efficiency reducing the } \\
\text { utilization of natural resources }\end{array}$ & $\begin{array}{l}\mathrm{I}_{1} \text { - ratio (on annual basis) between the economic value of } \\
\text { the wood harvested per cubic meter and forest area }\left(€ \mathrm{~m}^{-3}\right. \\
\left.\mathrm{yr}^{-1}\right) \\
\mathrm{I}_{2}-\mathrm{CO}_{2} \text { emissions of the phases of forest-wood chain (from } \\
\text { the felling to the transport) for unit volume }\left(\mathrm{kgCO}_{2} \mathrm{~m}^{-3}\right)\end{array}$ \\
\hline Reuse & $\begin{array}{l}\text { Life span of products/Products } \\
\text { re-utilization before its disposal }\end{array}$ & $\begin{array}{l}\mathrm{I}_{3} \text { - product life span before to be used for energy generation } \\
\text { (years) }\end{array}$ \\
\hline Recycle & $\begin{array}{l}\text { Level of recyclability of the } \\
\text { products for other purpose/ } \\
\text { objects (paper, animal bedding, } \\
\text { chipboard panels) }\end{array}$ & $\begin{array}{l}\mathrm{I}_{4} \text { - economical differential between the potential economic } \\
\text { value of the wood assortment and the real value earned (\%) }\end{array}$ \\
\hline Recover & $\begin{array}{l}\text { Energy production from the } \\
\text { „end-of-life products” }\end{array}$ & $\begin{array}{l}\mathrm{I}_{5} \text { - ratio between } \mathrm{CO}_{2} \text { emissions saved by the timber sold } \\
\text { for energy production (respect to the diesel oil) and the total } \\
\text { cubic meter collected }\left(\mathrm{kgCO}_{2} \mathrm{~m}^{-3}\right) \\
\mathrm{I}_{6} \text { - ratio between deadwood used for energy purpose and } \\
\text { total deadwood in forest }\left(\mathrm{m}^{3} \mathrm{~m}^{-3}\right)\end{array}$ \\
\hline
\end{tabular}


$I_{1}=\frac{\text { Annual economic value }}{\text { Cubic meter of wood harvested }}\left[\frac{€}{m^{3} y r}\right]$

$I_{2}=\frac{\mathrm{CO}_{2} \text { emissions in the forest - wood chain }}{\text { Wood volume harvested }}\left[\frac{\mathrm{KgCO}_{2}}{\mathrm{~m}^{3}}\right](2)$

A high value of $I_{1}$ means that high quality wood (i.e. for building or furnishing) is produced; conversely, a low value means that low quality wood (e.g., woodchips or pellets) is obtained. It is important to highlight that this indicator is closely linked to local site and forest stand characteristics (e.g., soil fertility, forest type).

The indicator $\mathrm{I}_{2}$ considers the $\mathrm{CO}_{2}$ emissions produced by the different forest-wood chain phases (felling, harvesting, chipping, transport to wood processing industries or to heating biomass plant). By means of $\mathrm{I}_{2}$ is possible to evaluate and compare the $\mathrm{CO}_{2}$ emissions of different forest management scenarios. This indicator assesses the performance of the production process in terms of $\mathrm{CO}_{2}$ emissions, in accordance with the basic principles of the bioeconomy. Lower is the $\mathrm{I}_{2}$ value, higher is the environmental sustainability of the process.

Reuse. Reuse refers to the chance of reutilization of a product in a new way, after performing its primary function. Reuse can be quantified considering the sum of life span of one wood product reused one or several times before being converted into energy. Anderle et al. (2002) estimated the following life span for five different wood products: 6 months for woodchips and pellets; 2 years for paper; 3 years for packaging (i.e. pallets, stock); 10-30 years for furnishing; and 15-35 years for building timber.

In this study, Reuse of the wood products obtained from the silvicultural treatments has been evaluated by means of $\mathrm{I}_{3}$ indicator (eq.3):

$$
I_{3}=\text { life time of the wood product }[y r]
$$

A high value of $\mathrm{I}_{3}$ means a long-life span of the wood products that it can be reused several times.

Recycle. Recycle is the process of separating materials in order to obtain high and/or low-quality sub-products. This principle has been applied to the forest-wood chain considering the destination of the wood harvested and the potential times that a product can be recycled. Recycle is evaluated by means of $\mathrm{I}_{4}$ indicator defined as follows (eq.4):

$I_{4}=\frac{\text { Potential earning - Effective earning }}{\text { Effective earning }}[\%]$

$\mathrm{I}_{4}$ expresses the economic differential (in \%) obtainable from a more rational valorization of the valuable wood assortments. The latter are those that generally have longer life times and create added value throughout the forest-wood supply chain.

Recover. Recover is the energy production from the "exhausted products". In the present study, Recover was quantified for the forest-wood chain using the following two indicators (eq. 5 and 6):

$I_{5}=\frac{\text {-Emission saved from the } \mathrm{C} \text { biogenic combustion }}{\text { Wood harvested }}$

$I_{6}=\frac{\text { Deadwood collected for energy generation }}{\text { Deadwood available in forest }}$

Since wood is considered "carbon neutral" in the bioenergetics cycle (Berndes et al. 2016), the emission generated by the carbon content in the woody biomass, called biogenic carbon, are usually neglected in the estimation of the combustion impact on the climate change. Considering the amount of wood used for energy purpose, Is evaluates the amount of $\mathrm{CO}_{2}$ generated by the $\mathrm{C}$ biogenic, considering the amount of fossil fuels saved. The value of this indicator can significantly change according to the destination of the wood harvested. A high value means that the timber collected is mainly employed for energy purpose, saving fossil fuels and decreasing the non-biogenic $\mathrm{CO}_{2}$ emissions.

The last indicator ( $\mathrm{I}_{6}$ ) measures the ratio be- 
tween the deadwood - all non-living woody biomass not contained in the litter, either standing, lying on the ground, or in the soil - removed during the silvicultural treatments and the total volume of deadwood. Deadwood can be considered an "end-of-life product", consequently this indicator measures the deadwood valorization capacity for energy purpose. This indicator is closely related with the initial deadwood stock.

In Table 2 the $4 \mathrm{R}$ framework and the relative indicators are summarized. The indicators values have been calculated after the two silvicultural treatments in Monte Morello forest.

\section{Multiple-Criteria Decision Analysis (MCDA)}

A Multiple-Criteria Decision Analysis (MCDA) has been performed to test the reliability and efficiency of the six above-mentioned indicators to assess the forest-wood chain.

The MCDA is a useful tool to identify the optimum result/solution in complex scenarios, where many actors are involved, with multiple aspects (e.g., ecological, social, economic, technical, ethical) and interests not directly comparable (Munda 2016). A MCDA requires: (1) a complex problem to be solved; (2) the definition of available alternatives; (3) the identification of the criteria and indicators (C\&I) to be evaluated; (4) a criteria priority index. The optimum solution is found comparing the available alternatives according to the criteria's priority order (from the most important to the least) and the values taken by the indicators. The main theoretical axiom of MCDA is that, first, the utility of an alternative is the indication of its desirability, and second, that an alternative A with higher utility should be preferred to an alternative B with lower utility. The optimum solution indicated by the analysis should load to utility maximization. A paradox of this approach is that the optimum solution is related to the method adopted and the weights assigned to the criteria as underlined by Greenstein (2017). However, in many 128 cases the decision makers are unable to weight their expected benefits.

An MCDA can be run with several different methods, that must be chosen according to the type of problem and the function/indicators defined. The application of MCDA to forest management and planning, is a useful tool for helping decision makers in the evaluation of different management actions (Kangas et al. 2008, Wolfslehner \& Seidl 2010, Uhde et al. 2015, Nilsson et al. 2016, Acosta \& Corral 2017). MCDA methods can be grouped in three main families (Table 3 ).

In the present study, the Analytical Hierarchical Process (AHP) has been chosen to perform the MCDA. AHP follows a full aggregation approach and it is a utility-based model, simple, flexible, and intuitive with the ability to handle qualitative and quantitative criteria. AHP has been adopted in several applications in forestry such as for multiple-use forestry and participatory planning (Mendoza \& Dalton 2005), for the implementation of criteria and indicators of the Sustainable Forest Management (Wolfslehner et al. 2005), for protected area and Natura 2000 sites collaborative management (Brescancin et al. 2018).

Five alternative forest management scenarios have been defined changing forest management practices (selective thinning and traditional thinning) and wood outcomes (woodchips and other wood products).

Scenario A: business-as-usual (test case: traditional and selective thinning, woodchips production).

Scenario B: traditional thinning; $100 \%$ of the wood harvested is chipped and delivered to the combined heat and power (CHP) plant closed to Monte Morello forest.

Scenario C: selective thinning; $100 \%$ of the wood harvested is chipped and delivered to the CHP plant closed to Monte Morello forest.

Scenario D: traditional thinning and wood valorization according to the characteristics of the wood harvested (diameter and length): $4 \%$ large poles for environmental engineering works, $37 \%$ for wood packaging. The wood 
Table 3 Main approaches and methods of MCDA

\begin{tabular}{|c|c|c|c|}
\hline \multirow{3}{*}{ 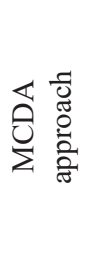 } & Full aggregation approach & \multirow{3}{*}{$\begin{array}{l}\frac{n}{0} \\
\tilde{E} \\
\sum\end{array}$} & $\begin{array}{l}\text { Compensative methods. i.e.: AHP, SAW, MAUT, MAVT, } \\
\text { MACBETH, ANP }\end{array}$ \\
\hline & Outranking approach & & $\begin{array}{l}\text { Partially compensatory methods. i.e.: ELECTRE, } \\
\text { PROMETHEE, REGIME, NAIADE }\end{array}$ \\
\hline & $\begin{array}{l}\text { Goal or reference level } \\
\text { approach }\end{array}$ & & $\begin{array}{l}\text { A goal for each criterion is defined. i.e.: EXPECTED } \\
\text { VALUE, STEP, TOPSIS }\end{array}$ \\
\hline
\end{tabular}

processing enterprises are located respectively at 15 and $20 \mathrm{~km}$ from the timber storage point. The remaining wood $(58 \%)$ is chipped and delivered to the CHP plant closed to Monte Morello forest.

Scenario E: selective thinning and wood valorization: 16\% large poles for environmental engineering works, $27 \%$ for wood packaging. The wood processing enterprise are located respectively at 15 and $20 \mathrm{~km}$ from the timber storage point. The remaining wood $(57 \%)$ is chipped and delivered to the CHP plant closed to Monte Morello forest.

The criteria's tree and concerning indicators (I) are structured as shown in Figure 1. The values of the six circular bioeconomy indicators were calculated for each scenario. $\mathrm{I}_{1}$ was computed as net profit gain, while the $\mathrm{CO}_{2}$ emissions $\left(\mathrm{I}_{2}\right)$ were calculated based on the data collected in the field (Table 4. I 3 was calculated as a weighted average of the expected life span of the wood products. I 4 was calculated using wood volume and local selling prices of the potential obtainable high value

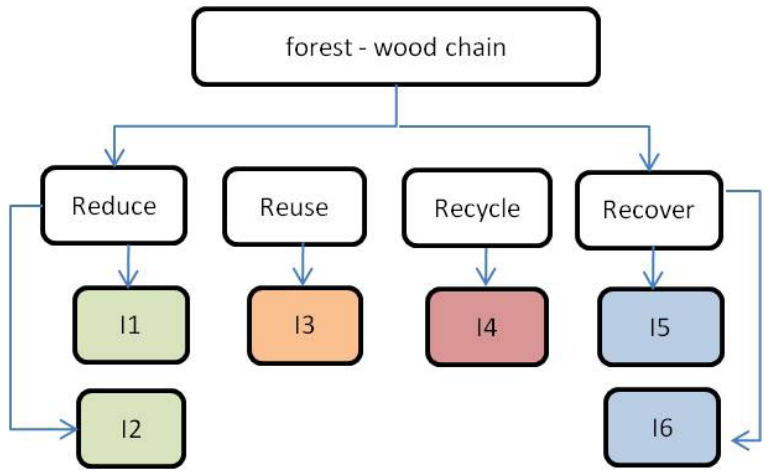

Figure 1 Structure of the criteria's tree wood products (Table 5 and 6). Is was calculated considering a $\mathrm{CO}_{2}$ avoided value of $3.23 \mathrm{~kg}$ $\mathrm{CO}_{2} \mathrm{~kg}^{-1}$ diesel considering an energy efficiency of $85 \%$. Lastly, I6 was estimated based on the ecological role of deadwood and the total amount of deadwood volume in site.

The weights of circular bioeconomy indicators were assigned through a pairwise comparison considering the hierarchical position of the $4 R s\left(I_{1}=I_{2}>I_{3}>I_{4}>I_{5}=I_{6}\right)$. The weights assigned were the following: $\mathrm{I}_{1}=0.355, \mathrm{I}_{2}=$ $0.355, \mathrm{I}_{3}=0.168, \mathrm{I}_{4}=0.083, \mathrm{I}_{5}=0.039, \mathrm{I}_{6}=$ 0.039 .

Once defined the indicators and the criteria priority index, the following steps were performed: (1) Definition of the evaluation matrix; (2) Standardization of the matrix (required for several methods); (3) Weight assignment; (4) Priorities calculation; (5) Robustness analysis. Regarding the second step, the evaluation matrix has been normalized according to the maximum criteria; $\mathrm{I}_{1}, \mathrm{I}_{3}, \mathrm{I}_{5}$ (with positive sign) and $\mathrm{I}_{6}$ are considered as a benefit, $\mathrm{I}_{2}$ and $\mathrm{I}_{4}$ are considered as a cost. The weight of each indicator is shown in Figure 2.

Then, the AHP has been applied to the five forest management scenarios using the software Definite 3.1 (https://spinlab.vu.nl/support/tools/ definite-bosda/) developed by Spinlab of Vrije Universiteit, Amsterdam.

From the methodological point of view, the five forest management scenarios were compared in pairs producing a reciprocal matrix $(A)$ where the relative weight is expressed as aij and it is located at the right side of the 
Table 4 Number of workers, average productivity and $\mathrm{CO}_{2}$ emissions in the forest-wood chain phases

\begin{tabular}{lcccrr}
\hline Phase & Workers & $\begin{array}{l}\text { Working } \\
\text { time }(\mathrm{h})\end{array}$ & $\begin{array}{l}\text { Average productivity } \\
\left(\mathrm{t} \mathrm{h}^{-1}\right)\end{array}$ & $\begin{array}{l}\text { Fuel consumption } \\
(\mathrm{l})\end{array}$ & \multicolumn{2}{c}{$\begin{array}{l}\mathrm{CO}_{2} \text { emissions } \\
\left(\mathrm{kg} \mathrm{CO}_{2} \mathrm{t}^{-1}\right)\end{array}$} \\
\hline Felling & $2-4$ & 756 & 1.60 & 454 gasoline & 0.86 \\
\hline Harvesting & $2-4$ & 504 & 2.40 & 2318 diesel & 5.10 \\
\hline Chipping & 2 & 120 & 10.10 & 2400 diesel & 5.20 \\
\hline Transport & Truck & - & 20.00 & 210 diesel & 0.46 \\
\hline Total & & & & & 11.62 \\
\hline
\end{tabular}

diagonal, whereas its reciprocal is defined as 1/aij and it is located in the opposite side of the diagonal.

$$
A=\left(a_{i j}\right)=\left(\begin{array}{cccc}
w_{1} / w_{1} & w_{1} / w_{2} & \ldots & w_{1} / w_{n} \\
w_{2} / w_{1} & w_{2} / w_{2} & \ldots & w_{2} / w_{n} \\
\cdot & \cdot & \cdot & \cdot \\
\cdot & \cdot & \cdot & \cdot \\
\cdot & \cdot & \cdot & \cdot \\
w_{n} / w_{1} & w_{n} / w_{2} & \ldots & w_{n} / w_{n}
\end{array}\right)
$$

In the matrix, the row indicates the relative weight of each forest management scenario compared to the others. When $i=j$, then $a i j=1$.

Then, the transpose of the vector of the weights $w$ is multiplied by matrix $A$ to obtain the vector represented by $\lambda_{\max } w$, that follows the principle:

$$
\left(A-\lambda_{\max } I\right) w=0
$$

where: $\lambda_{\max }$ - largest Eigenvalue of matrix A $\lambda_{\max } \mathrm{W}, I$ - identity matrix of size $n, n$ - number of rows or columns in the matrix.

Normalizing the vector $\mathrm{w}$ so that the sum of its elements is equal to 1 , it is possible to calculate the priority value $(\mathrm{P})$ for each forest management scenario:

$$
P=\frac{w}{\sum_{i=1}^{n} w(i)}
$$

Finally, the priority values of the five forest management scenarios were compared in order to identify the most suitable scenario ac- cording to the circular bioeconomy principles.

\section{Results}

\section{Forest-wood chain analysis}

The forest-wood chain phases considered in the study are: felling and harvesting; chipping; wood transport (from forest to biomass-based plant or wood processing enterprise) and energy conversion. For each phase, the materials flow and the $\mathrm{CO}_{2}$ emissions produced by forest-wood chain phases have been estimated.

\section{Felling and harvesting}

The results show that after the traditional thinning, $24 \%$ of the growing stock was har-

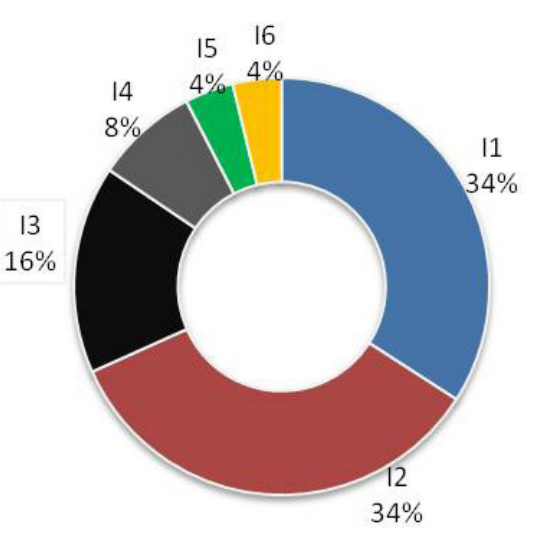

Figure 2 Weight of the circular bioeconomy indicators 
Table 5 Potential wood assortments based on diameter distribution

\begin{tabular}{ccc}
\hline Diametric class $(\mathrm{cm})$ & Large pole $\left(\mathrm{m}^{3} \mathrm{ha}^{-1}\right)$ & Packaging $\left(\mathrm{m}^{3} \mathrm{ha}^{-1}\right)$ \\
\hline Selective thinning & & - \\
\hline 20 & 0.58 & - \\
\hline 25 & 8.89 & - \\
\hline 30 & 28.16 & 12.94 \\
\hline 35 & 14.44 & 23.11 \\
\hline 40 & 7.95 & 36.06 \\
\hline Total & 60.02 & - \\
\hline Traditional thinning & & - \\
\hline 20 & 1.65 & - \\
\hline 25 & 15.22 & 6.32 \\
\hline 30 & 29.60 & - \\
\hline 35 & 7.05 & 6.32 \\
\hline 40 & &
\end{tabular}

Source: adapted from Cantiani et al. (2017).

Table 6 Characteristics of the five forest management scenarios

\begin{tabular}{llllll}
\hline Scenario & $\begin{array}{l}\text { Thinning method } \\
\text { (T= traditional, }\end{array}$ & $\begin{array}{l}\text { Wood volume } \\
\left(\mathrm{m}^{3}\right)\end{array}$ & Wood volume allocation & \\
\cline { 4 - 6 } & $\mathrm{S}=$ selective $)$ & & Woodchips $\left(\mathrm{m}^{3}\right)$ & Packaging $\left(\mathrm{m}^{3}\right)$ & $\begin{array}{l}\text { Large poles } \\
\left(\mathrm{m}^{3}\right)\end{array}$ \\
\hline $\mathrm{A}$ & $\mathrm{T}+\mathrm{S}$ & 1,813 & 1,813 & - & - \\
\hline $\mathrm{B}$ & $\mathrm{T}$ & 1,454 & 1,454 & - & - \\
\hline $\mathrm{C}$ & $\mathrm{S}$ & 2,220 & 2,220 & - & - \\
\hline $\mathrm{D}$ & $\mathrm{T}$ & 1,454 & 850,000 & 535 & 63 \\
\hline
\end{tabular}

vested on 5.35 ha, while in the area managed with selective thinning (4.73 ha), the harvested rate is $36 \%$ (Table 1 ). In addition, a deadwood volume of $9.5 \mathrm{~m}^{3} \mathrm{ha}^{-1}$ and $18.2 \mathrm{~m}^{3} \mathrm{ha}^{-1}$ was removed with traditional and selective thinning, respectively.

The forestry operations were performed by means of two medium chainsaws Stihl MS180, 2 Lamborghini tractors with winch and a Terex TC125 crawler with Deutz TCD 2012 L04 engine (engine power $74.0 \mathrm{~kW}$ ) equipped with forest gripper. The site productivity was estimated in $1 \mathrm{t} \mathrm{h}^{-1}$ for the felling phase and $2.4 \mathrm{t}$ $\mathrm{h}^{-1}$ for the harvesting phase.

For the harvesting action, the fuel consumptions of the chainsaws and the forest tractor was of 4541 (average consumption $0.6 \mathrm{l} \mathrm{h}^{-1}$ ) and 2,318 1 (average consumption of $41 \mathrm{~h}^{-1}$ ) respectively. For the estimation of the $\mathrm{CO}_{2}$ emissions during all forest-wood chain phases the following values were adopted (EPA 2005): $2.65 \mathrm{~kg} \mathrm{CO}_{2} \mathrm{l}^{-1}$ of gasoline and $2.38 \mathrm{~kg} \mathrm{CO}_{2} \mathrm{l}^{-1}$ of diesel fuel. From these values the $\mathrm{CO}_{2}$ emissions were estimated (Table 4): $1,043 \mathrm{~kg} \mathrm{CO}_{2}$ for felling and $6,143 \mathrm{~kg} \mathrm{CO}_{2}$ for harvesting. 
Chipping

Regarding chipping phase, $1,813 \mathrm{~m}^{3}$ of wood $\left(1,042 \mathrm{~m}^{3}\right.$ from selective thinning and $771 \mathrm{~m}^{3}$ from traditional thinning) were collected (average moisture content of $45 \%$ ) and chipped in forest.

Two workers and a chipper fixed on the rear axle of a TIMBERJACK OY forwarder model Timberjack 1110D were employed, for a productivity of $10.1 \mathrm{t} \mathrm{h}^{-1}$. The fuel consumption was of 2,400 1 with $\mathrm{CO}_{2}$ emissions equal to $6,360 \mathrm{~kg} \mathrm{CO}_{2}$ (Table 4).

The $\mathrm{CO}_{2}$ emissions were estimated for the two different thinning techniques: $3.41 \mathrm{~kg} \mathrm{CO}_{2}$ $\mathrm{m}^{-3}$ wood for the traditional thinning, and $3.92 \mathrm{~kg}$ $\mathrm{CO}_{2} \mathrm{~m}^{-3}$ wood for the selective thinning.

\section{Transport}

The woodchip was delivered to the CHP plant in the Calenzano municipality $\left(43^{\circ} 51^{\prime} 24^{\prime \prime} \mathrm{N}\right.$; $\left.11^{\circ} 09^{\prime} 49^{\prime \prime} \mathrm{E}\right), 12 \mathrm{~km}$ far from the Monte Morello forest. The woodchip was transported by means of a truck with a capacity of 28-30 t. The average productivity was around $20 \mathrm{t} \mathrm{h}^{-1}$ (considering loading, transport,unloading phases). For the $\mathrm{CO}_{2}$ emissions calculation a fuel consumption value of 20.41 for $100 \mathrm{~km}$ and an emission value of $2.65 \mathrm{~kg} \mathrm{CO}_{2} \mathrm{l}^{-1}$ was considered. A total of $563 \mathrm{~kg} \mathrm{CO}$ emissions was estimated for the amount of wood transported.

\section{Wood products allocation on the market}

The wood volume has been totally chipped and delivered to the CHP plant. The CHP plant has a thermal power of 5.9 MW (woodchips consumption of $50 \mathrm{t} \mathrm{d}^{-1}$, thermal efficiency $85 \%$ ) and an electric power of $800 \mathrm{~kW}_{\mathrm{el}}$. Approximately 1,215 $\mathrm{t}$ of woodchip were produced (moisture content 30\%, low heating value of 3.4 $\mathrm{MWh} \mathrm{t}^{-1}$ ). The use of the woodchip for heat production, compared to the use of natural gas and heating oil, allows to save, respectively, 207 and $278 \mathrm{~g} \mathrm{CO}_{2} \mathrm{kWh}^{-1}$.

\section{Circular bioeconomy indicators}

\section{Reduce}

For the first indicator $\mathrm{I}_{1}$, the production process efficiency has been estimated as ratio between the average annual income per cubic meter and the managed forest area. I was calculated using the following equation (eq. 7):

$I_{1}=\frac{a}{V_{h}}\left[€ / m^{3}\right]$ with $a=\frac{\text { Pm. } r}{(1+r)^{n_{-1}}}$ where:

$a$ - average annual income deriving from the sale of wood products, $P m$ - net profit gain for year $m, r$ - interest rate, $n$ - numbers of years among two subsequent thinning (15 years), $V_{h}$ harvested volume per ha $\left(\mathrm{m}^{3} \mathrm{ha}^{-1}\right)$.

The period of 15 years among two thinning is derived from the forest management prescription by the LIFE CCM/IT/905 FoResMit project.

Currently, the local woodchip price is $37 €$ $\mathrm{t}^{-1}$ (with a moisture content of $45 \%$ ), as derived by means of interviews with local forest enterprises. Using this woodchip value, the ratio between economic value of wood harvested per cubic meter and surface $\left(\mathrm{I}_{1}\right)$ is $2.34 € \mathrm{~m}^{-3}$ $\mathrm{yr}^{-1}$, while the $\mathrm{CO}_{2}$ emissions related to the forest-wood chain in Monte Morello $\left(\mathrm{I}_{2}\right)$ are 7.78 $\mathrm{kg}_{\mathrm{CO} 2} \mathrm{~m}_{\text {wood }}^{-3}$. In particular, the $\mathrm{CO}_{2}$ emissions considered for the calculation of $\mathrm{I}_{2}$ are the emission generated by the whole forest-wood chain up to the CHP plant (see Table 4).

\section{Reuse}

The indicator $\mathrm{I}_{3}$ is measured as sum of the years of life of one wood product reused one or several times.The following values were for the wood products life span: 6 months for woodchip; 3 years for packaging; and 30 years for large poles used for environmental engineering works (e.g., simple or double palisade).

In the business-as-usual scenario, all the wood volume harvested is chipped and deliv- 
ered to the CHP plant located in the Calenzano municipality. Consequently, the total life span of wood assortments (only woodchips) retired by Monte Morello forest $\left(\mathrm{I}_{3}\right)$ is equal to 0.5 years (6 months).

\section{Recycle}

The indicator $\left(\mathrm{I}_{4}\right)$ indicates in which percentage it is possible to improve the earnings from the timber selling. The idea is that higher is the economic value of the products higher is the potential number of recycling cycles. In Monte Morello case study, the wood harvested by thinning can be suitable for three different markets: (1) large pole for environmental engineering works (local product) - selling price 40 $€ \mathrm{~m}^{-3}$; (2) pallets and wood packaging - selling price $35 € \mathrm{~m}^{-3}$; (3) woodchips (with a moisture content of $45 \%$ ) - selling price $33 € \mathrm{~m}^{-3}$.

The potential wood volumes available was estimated considering the wood characteristics required for large pole production (5-5.4 m length, diameter range $18-30 \mathrm{~cm}$ ) and for pallets production ( $4 \mathrm{~m}$ length and diameter above $30 \mathrm{~cm}$ ) as pointed out by Cantiani et al. (2017) (see Table 5). The potential revenue from the timber selling is equal to $55,200 €$ so divided: $22,807 €$ from large poles $(11,355 €$ from selective thinning and $11,452 €$ from traditional thinning), 7,153 $€$ from timber for packaging $(5,970 €$ from selective thinning and $1,183 €$ from traditional thinning) and 25,242 $€$ from woodchips. The earning from the woodchip's sale has been calculated deducting $9 € \mathrm{~m}^{-3}$ as chipping costs. $\mathrm{I}_{4}$ is equal to $25.3 \%$, it means that the business-as-usual scenario can be improved.

\section{Recover}

Recover was evaluated through two indicators. The first Indicator $\left(\mathrm{I}_{5}\right)$ deals with the concept of "carbon neutrality" of the bioenergy system. The emissions saved have been calculated considering replacing diesel fuel with wood- chips (diesel fuel emission value: $3.2 \mathrm{kgCO}_{2}$ $\mathrm{kg}^{-1}$ diesel fuel $)$.

The second Indicator $\left(\mathrm{I}_{6}\right)$ emphasized the opportunity of using deadwood for energy purpose without compromising the ecological function provided by this component of forest ecosystem. This indicator highlighted that for the Monte Morello forest more than 30\% $\left(\mathrm{I}_{6}=0.37\right)$ of the deadwood can been used for energy purposes.

Generally, on the long-term period it would be a good practice to leave at least $5 \%$ of deadwood, - particularly logs with minimum diameter above $30 \mathrm{~cm}$ - because they are of primary importance both for biodiversity (e.g., saproxylic species) and for preservation of soil fertility (Nordén et al. 2004, Pastorelli et al. 2017).

\section{Forest management scenarios}

The results of the AHP method are shown in Figure 3, Table 7 (pay-off matrix) and Table 8 (standardized matrix). Scenario $\mathrm{C}-$ selective thinning with economic valorization of the wood products- is considered the optimumforest management solution according to the circular bioeconomy principles, with respect of the index priority order given by the $4 R$ framework.

To test the robustness of the results, an uncertainty analysis was performed changing the weights and score values of $+/-20 \%$ with the Monte Carlo simulation, by means of the DEFINITE software. The output is a probability table of the position covered by each scenario $\left(1^{\text {st }}\right.$ position scenario $E 99 \%$ of times, $2^{\text {nd }}$ position scenario D $98 \%$ of times, $3^{\text {rd }}$ position scenario $89 \%$ of times, $4^{\text {th }}$ position scenario A $86 \%$ of times and $5^{\text {th }}$ position scenario B 97\% of times). The solution proposed by the AHP can be declared "robust" since the scenario E is in the first position $99 \%$ of times.

The results shows the scenario E as the optimum one (selective thinning) since it allows to reach higher prescribed cut (52\% compared to the traditional thinning). However, even 
if with the selective thinning the volume of wood harvested is remarkable higher than with the traditional one, the score reached by scenario D (traditional thinning, wood products valorization) is high. This can be explained considering the destination of the wood volume harvested. In the scenario D, $37 \%$ of the

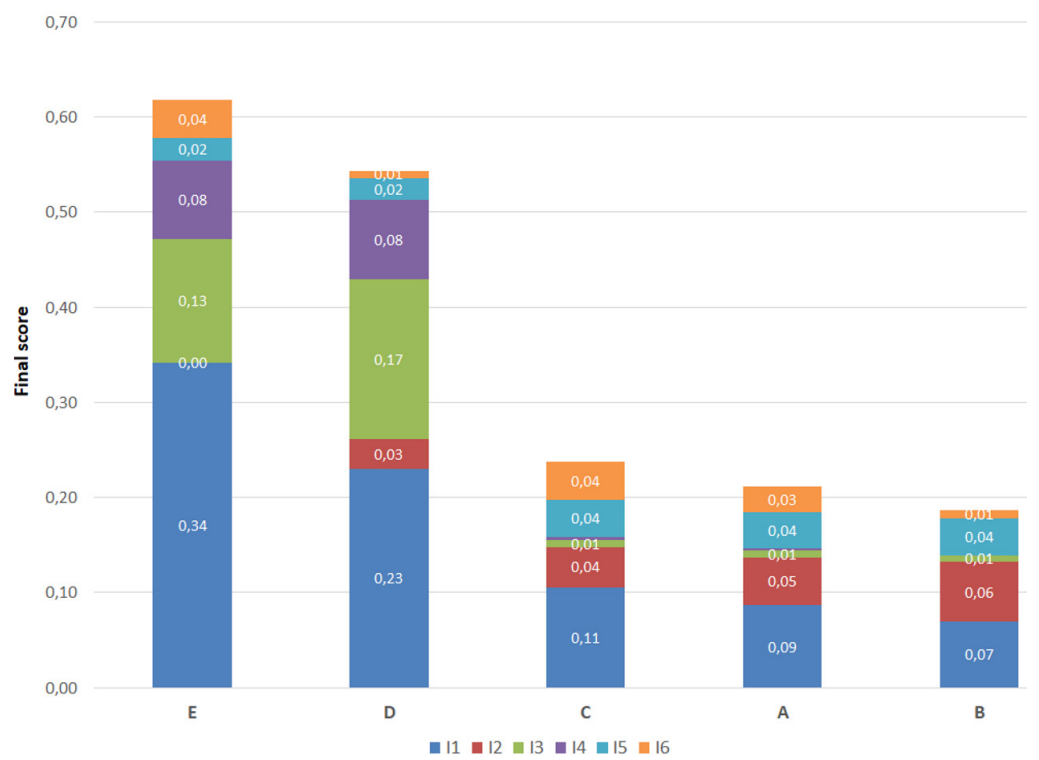

Figure 3 Final scores of indicators for each forest management scenario wood volume harvested is sold for large pole production (59\% for woodchips and $4 \%$ for packaging), which is a local, well paid product, since it requires logs with specific characteristics. In the scenario E, only $27 \%$ of the wood harvested is suitable for pole $(56 \%$ for woodchips and $16 \%$ for packaging). This leads the scenario $\mathrm{D}$ to reach a high score.

The scores reached by the scenarios $\mathrm{A}, \mathrm{B}$ and $\mathrm{C}$, are considerably lower than $\mathrm{D}$ and E, however, useful indications can be drawn. Currently, the wood volume harvested in Monte Morello forest is totally used for energy production. Looking at the scenarios $\mathrm{A}, \mathrm{B}$ and $\mathrm{C}$ is clear that, if the timber collected is entirely aimed to woodchips, the se-

Table 7 Payoff matrix for each forest management scenario

\begin{tabular}{lllrlll}
\hline Scenario & $\mathrm{I}_{1}\left(€ \mathrm{ha}^{-1}\right)$ & $\mathrm{I}_{2}\left(\mathrm{kgCO}_{2} \mathrm{~m}^{-3}\right)$ & $\mathrm{I}_{3}(\mathrm{y})$ & $\mathrm{I}_{4}(\%)$ & $\mathrm{I}_{5}\left(\mathrm{kgCO}_{2} \mathrm{~m}^{-3}\right)$ & $\mathrm{I}_{6}\left(\mathrm{~m}^{3} \mathrm{~m}^{-3}\right)$ \\
\hline A & 2.34 & 7.80 & 0.50 & 0.30 & -634 & 0.37 \\
\hline B & 2.34 & 7.50 & 0.50 & 0.30 & -634 & 0.10 \\
\hline C & 2.34 & 8.00 & 0.50 & 0.20 & -634 & 0.50 \\
\hline D & 7.80 & 8.30 & 11.60 & 0.00 & -371 & 0.10 \\
\hline E & 7.57 & 8.40 & 8.90 & 0.00 & -359 & 0.50
\end{tabular}

Table 8 Standardize matrix for MCDA

\begin{tabular}{ccccccc}
\hline Scenario & $\mathrm{I}_{1}\left(€ \mathrm{ha}^{-1}\right)$ & $\mathrm{I}_{2}\left(\mathrm{kgCO}_{2} \mathrm{~m}^{-3}\right)$ & $\mathrm{I}_{3}(\mathrm{y})$ & $\mathrm{I}_{4}(\%)$ & $\mathrm{I}_{5}\left(\mathrm{kgCO}_{2} \mathrm{~m}^{-3}\right)$ & $\mathrm{I}_{6}\left(\mathrm{~m}^{3} \mathrm{~m}^{-3}\right)$ \\
\hline $\mathrm{A}$ & 0.30 & 0.15 & 0.04 & 0.02 & 1.00 & 0.74 \\
\hline $\mathrm{B}$ & 0.30 & 0.18 & 0.04 & 0.00 & 1.00 & 0.20 \\
\hline $\mathrm{C}$ & 0.30 & 0.12 & 0.04 & 0.04 & 1.00 & 1.00 \\
\hline $\mathrm{D}$ & 1 & 0.09 & 1.00 & 1.00 & 0.59 & 0.20 \\
\hline $\mathrm{E}$ & 0.97 & 0.00 & 0.77 & 1.00 & 0.57 & 1.00 \\
\hline
\end{tabular}


lective thinning method is the most suitable, according to the $4 \mathrm{R}$ framework of the circular bioeconomy.

\section{Discussion}

Applying the "cascade" principle to the forest sector, pushing the timber utilization mainly for wood products than for energy production could be a possible good alternative in accordance with the circular bioeconomy principles. However, the main factors that influence the identification of the optimum forest management scenario are: local market demand for timber and biomass for energy use.

In the present study, the wood harvested was totally chipped due to the low quality of the raw material harvested. Therefore, three indicators $\left(\mathrm{I}_{1}, \mathrm{I}_{3}\right.$ and $\left.\mathrm{I}_{4}\right)$ highlight that for this reason local forest managers have not adopted the optimum solution in the allocation of the wood products provided by Monte Morello forest. In fact, all wood volume harvested was allocated for woodchips production for two main reasons: low wood qualitative characteristics and high local price of woodchip compared to the other wood products (Pra \& Pettenella 2016, Marchi et al. 2018).

However, some thinning types yield a higher harvesting rate and a higher percentage of quality roundwood. According to the "cascade" approach, the optimal solution should be the market allocation of a greater share of high value wood products with a longer life span. In the case study of Monte Morello, the AHP results show that the forest owner couldincrease their income of $25 \%$ compared to current income. These results are in accordance with the review by Cameron (2002) evidencing that the selective thinning is profitable because improves future wood quality and consequently economic value of the products. In addition, the alternative wood products (poles for environmental engineering, wood for packaging or other wood assortments with a long- life span) would store carbon for longer times than woodchips for bioenergy production, with positive effects on the climate as underlined by other studies (Liu \& Han 2009). In a similar way, Mathieu et al. (2012) have estimated the impact of three different forest management scenarios on the carbon balance of the forest-wood product chain in a case study in France. The authors have compared three management scenarios with different rotation lengths and thinning schedules assessing the potential of harvested wood products carbon pool in each scenario.

The results of this study highlight that two indicators $\left(\mathrm{I}_{2}\right.$ and $\left.\mathrm{I}_{5}\right)$ show a favorable $\mathrm{CO}_{2}$ balance due to the low $\mathrm{CO}_{2}$ emissions during all forest-wood chain phases $\left(7.2 \mathrm{kgCO}_{2} \mathrm{~m}^{-3}\right)$ and a high quantity of emissions avoided thanks to the use of forest biomass rather than fossil fuels. Globally, the use of woodchips for energy production in CHP plant generates a saving of $0.9 \mathrm{Mg} \mathrm{GJ}^{-1}$. Other studies confirmed the favorable $\mathrm{CO}_{2}$ balance when harvesting residues are used to replace fossil fuels: Laganière et al. (2017) estimate that $\mathrm{CO}_{2}$ emission reductions vary from 0.8 to $3.9 \mathrm{Mg} \mathrm{GJ}^{-1}$ for heat production and from 0.1 to $9.2 \mathrm{Mg} \mathrm{GJ}^{-1}$ for power production using fast-growing trees to produce bioenergy. Besides, Geng et al. (2017) emphasized that harvested wood products and wood bioenergy originated from sustainably managed forests can significantly contribute to greenhouses gas (GHG) emissions reduction in the long term.

In addition, the results of the AHP show that the current forest management strategy could be largely improved, by means of the valorization of the timber harvested for wood packaging or building. For example, the wood packaging - such as wood pallets - are more environmentally-friendly than plastic pallets during the whole life cycle (Sathre et al. 2014).

Finally, the last indicator used in the present study emphasizes the role of deadwood as potential energy resource in the degraded forests. Deadwood is an important structural 
and multifunctional component of forests, but if the amount of standing dead trees and lying deadwood is too high - as in the Monte Morello case study - the risk of forest fires and biotic attacks increases. In these circumstances, the first two decay classes of deadwood can be partialy exploited for bioenergy production without compromising the ecological functionality.

\section{Conclusions}

The present study proposes a set of indicators and a methodology - based on AHP approach - aimed at identifying the most appropriate forest management scenario to optimize forest outcomes considering the principles of circular bioeconomy. The methodology proposed can support decision makers including the principles of EU Strategy for "Innovating for Sustainable Growth: A Bioeconomy for Europe" (2013) and "An EU action plan for the Circular Economy" (2015) in the forest management practices at local level.

The main advantages of the proposed method are that the results are clear and easy to understand in order to identify the optimum forest management scenario. In addition, field surveys and data collection are simple and require a short time-consuming. Another advantage of the proposed methodology is the possibility of comparing the outcomes of different forest management practices and study areas in a synthetic way.

Conversely, the main disadvantages are that a preliminary set of indicators should be integrated in order to exhaustively quantify all four Rs of circular economy and that the application of the method requires a basic level of knowledge of AHP. Another disadvantage is the high level of subjectivity in the weight assigned to the criteria, otherwise limited by the sensitivity analysis which reduces the influence of personal judgments by introducing uncertainty in the computations. Another disadvantage related to the AHP is that in some 136 cases is difficult to maintain the consistency index below the $10 \%$ threshold due to the incoherence of the answers provided by the respondents. Generally, lower values of consistency index are recorded when the sample is composed of experts.

However, it is important to remember that AHP is a tool of support in decision-making processes, but not a decision-maker itself. Consequently, outputs and results must be deeply analyzed and discussed before taking them for granted.

Finally, the future steps of the study will be the integration of the set of indicators and their application in other case studies to test the validity also in other contexts.

\section{References}

Acosta M., Corral S., 2017. Multicriteria decision analysis and participatory decision support systems in forest management. Forests 8(4): 116. DOI: 10.3390/ f8040116

Anderle A., Ciccarese L., Dal Bon D., Pettenella D., Zanolini E., 2002. Carbon stocking and sequestration in forests and wood products in Italy. Agenzia per la Protezione dell'Ambiente e per i Servizi Tecnici (APAT), Roma, p. 58. ISBN 88-448-0077-2

Berndes G., Abt B., Asikainen A., Cowie A., Dale V., Egnell G., Lindner M., Marelli L., Paré D., Pingoud K., Yeh S., 2016.Forest biomass, carbon neutrality and climate change mitigation. From science to Policy 3, European Forest Institute (EFI), Joensuu, p. 27.

Brescancin F., Dobšinská Z., De Meo I., Šálka J., Paletto A., 2018. Analysis of stakeholders' involvement in the implementation of the Natura 2000 network in Slovakia. Forest Policy and Economics 89: 22-30. DOI: 10.1016/j.forpol.2017.03.013

Bruhn T., Namis H., Olfe-Kräutlein B., 2016. Separating the debate on $\mathrm{CO}_{2}$ utilisation from carbon capture and storage. Environmental Science \& Policy 60: 38-43. DOI: 10.1016/j.envsci.2016.03.001

Cameron A.D., 2002. Importance of early selective thinning in the development of long-term stand stability and improved log quality: A review. Forestry 75: 25-35. DOI: $10.1093 /$ forestry/75.1.25

Cantiani P., Marchi M., Plutino M., 2017. SelPiBio life for the balck pine stand. A selvicultural strategy for artificial black pine forest stand with different functions and destinations). Sherwood 225: 21-24. DOI: 10.3832/ ifor1300-007

Ciccarese L., Pellegrino P., Pettenella D., 2014. A new 
principle of the European Union forest policy: the cascading use of wood products. Italian Journal of Forest and Mountain Environments 5(69): 285-290. DOI: 10.4129/ifm.2014.5.01

D’Amato D., Droste N., Allen B., Kettunen M., Lähtinen K., Korhonen J., Leskinen P., Matthies B.D., Toppinen A., 2017. Green, circular, bio economy: A comparative analysis of sustainability avenues. Journal of Cleaner Production 168: 716-734. DOI: 10.1016/j.jclepro.2017.09.053

De Meo I., Agnelli E.A., Graziani A., Kitikidou K., Lagomarsino A., Milios E., Radoglou K., Paletto A., 2017. Deadwood volume assessment in Calabrian pine (Pinus brutia Ten.) peri-urban forests: Comparison between two sampling methods. Journal of Sustainable Forestry 36(7): 1-21. DOI: 10.1080/10549811.2017.1345685

Ellen MacArthur Foundation, 2014. Towards the circular economy: Accelerating the scale-up across global supply chains. Web: http://www3.weforum.org/docs/ WEF_ENV_TowardsCircularEconomy_Report_2014. pdf. Accessed: 31.08 .2018

EPA, 2005. Average carbon dioxide emissions resulting from gasoline and diesel fuel. Office of Transportation and Air Quality, United States Environmental Protection Agency (EPA), Washington DC.

European Commission, 2008. Directive 2008/98/EC of the European Parliament and of the Council of 19 November 2008 on Waste and Repealing Certain Directives. European Commission, Bruxelles.

European Commission, 2012. Innovating for sustainable growth: a bioeconomy for Europe. Communication from the Commission to the European Parliament, the Council, the European economic and Social Committee and the Committee of the regions, Luxembourg COM (2012) 60 .

Geng A., Yang H., Chen J., Hong Y., 2017. Review of carbon storage function of harvested wood products and the potential of wood substitution in greenhouse gas mitigation. Forest Policy and Economics 85: 192-200. DOI: 10.1016/j.forpol.2017.08.007

Greenstein G., 2017. Paradox of multi criteria decision making processes. Universal Journal of Management 5(8): 395-403. DOI: 10.13189/ujm.2017.050804

Grilli G., Ciolli M., Garegnani G., Geri F., Sacchelli S., Poljanec A., Vettorato D., Paletto A., 2017a. A method to assess the economic impacts of forest biomass use on ecosystem services in a National Park. Biomass \& Bioenergy 98: 252-263. DOI: 10.1016/j.biombioe.2017.01.033

Grilli G., De Meo I., Garegnani G., Paletto A., 2017b. A multi-criteria framework to assess the sustainability of renewable energy development in the Alps. Journal of Environmental Planning and Management 7(60): 12761295. DOI: $10.1080 / 09640568.2016 .1216398$

Hetemäki L. (ed.), 2104. Future of the European Forest-Based Sector: Structural changes towards bioeconomy, What science can tell us 6. European Forest Institute, Joensuu, 2014, p. 108.
Hetemäki L., Hanewinkel M., Muys B., Ollikainen M., Palahi M., Trasobares A., 2017. Leading the way to a European circular bioeconomy strategy, From Science to Policy 5, European Forest Institute (EFI), Joensuu, p. 52.

Ishizaka A., Nemery P., 2013. Multi-criteria decision analysis, methods and software. Wiley and Sons, Chichester, p. 685. DOI: 10.1002/9781118644898

Kangas A., Kurttila M., Hujala T., Eyvindson K., Kangas J., 2008. Decision support for forest anagement. Springer Nature, Switzerland AG.

Klein D., Wolf C., Schulz C., Weber-Blaschke G., 2015. 20 years of life cycle assessment (LCA) in the forestry sector: state of the art and a methodical proposal for the LCA of forest production. The International Journal of Life Cycle Assessment 20(4): 556-575. DOI: 10.1007/ s11367-015-0847-1

Laganière J., Paré D., Thiffault E., Bernier P.Y., 2017. Range and uncertainties in estimating delays in greenhouse gases mitigation potential of forest bioenergy sourced from Canadian forests. GCB Bioenergy 9(2): 358-369. DOI: $10.1111 /$ gcbb. 12327

Liu G., Han S., 2009. Long-term forest management and timely transfer of carbon into wood products help reduce atmospheric carbon. Ecological Modelling 13-14(220): 1719-1723. DOI: 10.1016/j.ecolmodel.2009.04.005

Marchi M., Paletto A., Cantiani P., Bianchetto E., De Meo I., 2018. Comparing thinning system effects on ecosystem services provision in artificial black pine $(\mathrm{Pi}$ nus nigra J. F. Arnold) Forests. Forests 9: 188. DOI: 10.3390/f9040188

Mathieu F., François N., Nicolas R., Frédéric M., 2012. Quantifying the impact of forest management on the carbon balance of the forest-wood product chain: A case study applied to even-aged oak stands in France. Forest Ecology and Management 279: 176-188. DOI: 10.1016/j.foreco.2012.05.031

Mazza G., Agnelli A. E., Cantiani P., Chiavetta U., Doukalianou F., Kitikidou K., Milios E., Oefanoudakis M., Radoglou K., Lagomarsino A. (2019). Short-term effects of thinning on soil $\mathrm{CO}_{2}, \mathrm{~N}_{2} \mathrm{O}$ and $\mathrm{CH}_{4}$ fluxes in Mediterranean forest ecosystems. Science of The Total Environment: 651, 713-724. DOI: 10.1016/j.scitotenv.2018.09.241

Mendoza G.A., Dalton W.J., 2005. Multi-stakeholder assessment of forest sustainability: multi-criteria analysis and the case of the Ontario forest assessment system. The Forestry Chronicle 81: 222-228. DOI: 10.5558/ tfc $81222-2$

Mohan S.V., Modestra J.A., Amulya K., Butti S.K., Velvizhi G., 2016. A Circular Bioeconomy with Biobased Products from $\mathrm{CO}_{2}$ Sequestration. Trends in Biotechnology 34(6): 506-519. DOI: $10.1016 / \mathrm{j}$. tibtech.2016.02.012

Munda G., 2016. Multiple criteria decision analysis and sustainable development. In: Figueira J., Greco S., Ehrogott M. (eds), Multiple criteria decision analysis: state of the art surveys, Springer Nature, pp. 953-986. DOI: 
10.1007/0-387-23081-5_23

Murray A., Skene K., Haynes K., 2015. The circular economy: an interdisciplinary exploration of the concept and application in a global context. Journal of Business Ethics 3(140): 369-380. DOI: 10.1007/s10551-0152693-2

Nilsson H., Nordström E.M., Öhman K., 2016. Decision support for participatory forest planning using AHP and TOPSIS. Forests 7(5): 100. DOI: 10.3390/f7050100

Nordén B., Ryberg M., Götmark F., Olausson B., 2004. Relative importance of coarse and fine woody debris for the diversity of wood-inhabiting fungi in temperate broadleaf forests. Biological Conservation 117: 1-10. DOI: 10.1016/S0006-3207(03)00235-0

Pastorelli R., Agnelli A.E., De Meo I., Graziani A., Paletto A., Lagomarsino A., 2017. Analysis of microbial diversity and greenhouse gas production of decaying pine logs. Forests 8: 224. DOI: 10.3390/f8070224

Pehnt M., 2006. Dynamic life cycle assessment (LCA) of renewable energy technologies. Renewable Energy 31: 55-71. DOI: 10.1016/j.renene.2005.03.002

Pra A., Pettenella D., 2016. Consumption of wood biomass for energy in Italy: a strategic role based on weak knowledge. Italian Journal Forestry and Mountain Environment 71(1): 49-62. DOI: 10.4129/ifm.2016.1.03

Proskurina S., Sikkema R., Heinimö J., Vakkilainen E., 2016. Five years left e How are the EU member states contributing to the $20 \%$ target for EU's renewable energy consumption; the role of woody biomass. Biomass \& Bioenergy 95: 64-77. DOI: 10.1016/j.biombi- oe.2016.09.016

Sathre R., Gonzalez-Garcia S., 2014. Life cycle assessment (LCA) of wood-based building, materials, Woodhead Publishing Limited, pp. 311-337. DOI: 10.1533/9780857097729.2.311

Scheepens A.E., Vogtländer J.G., Brezet J.C., 2016. Two life cycle assessment (LCA) based methods to analyse and design complex (regional) circular economy systems. Case: making water tourism more sustainable. Journal of Cleaner Production 114: 257-268. DOI: 10.1016/j.jclepro.2015.05.075

Uhde B., Hahn W.A., Griess V.C., Knoke T., 2015. Hybrid MCDA methods to integrate multiple ecosystem services in forest management planning: a critical review. Environmental Management 56(2): 373-388. DOI: 10.1007/s00267-015-0503-3

Van Buren N., Demmers M., van der Heijden R., Witlox F., 2016. Towards a circular economy: the role of dutch logistics industries and government. Sustainability 8: 647. DOI: $10.3390 / \mathrm{su} 8070647$

Wolfslehner B., Vacik H., Lexer M.J., 2005. Application of the analytic network process in multi-criteria analysis of sustainable forest management. Forest Ecology and Management 207: 157-170. DOI: 10.1016/j.foreco.2004.10.025

Wolfslehner B., Seidl R., 2010. Harnessing ecosystem models and multi-criteria decision analysis for the support of forest management. Environmental Management 46(6): 850-861. DOI: 10.1007/s00267-0099414-5 